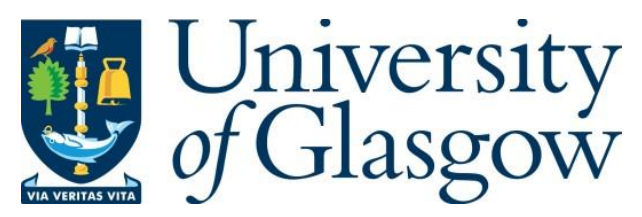

Young, G. (2017) From protection to repression: the politics of street vending in Kampala. Journal of Eastern African Studies, 11(4), pp. 714-733.

There may be differences between this version and the published version. You are advised to consult the publisher's version if you wish to cite from it.

http://eprints.gla.ac.uk/209347/

Deposited on: 4 February 2020

Enlighten - Research publications by members of the University of Glasgow http://eprints.gla.ac.uk 


\title{
From Protection to Repression: The Politics of Street Vending in Kampala ${ }^{* \dagger}$
}

\begin{abstract}
The political evolution of Kampala under the National Resistance Movement (NRM) has profoundly affected the fortunes of the city's street vendors. This article examines the effects of institutional changes brought about by the NRM's efforts to monopolize power in the city, arguing that the twin forces of democratization and decentralization allowed street vending to flourish while the reversal of these processes precipitated its dramatic decline. Democratization and decentralization initiated a period of intense political competition in which vendors could trade political support for protection from politicians who were more interested in political survival than the implementation of policy. This ability was lost when the central government introduced a new city government that shifted the balance of power from elected politicians to appointed technocrats. The new city government has since sought legitimacy through development and urban management initiatives that aim to transform Kampala into a supposedly modern, well-organized city. In doing so, it has sought to eradicate street vending, a practice it sees as the antithesis of and an obstacle to its ambitions. Lacking the channels for political influence that they previously enjoyed, street vendors have been forced to face the full brunt of government repression.
\end{abstract}

Keywords: Street Vending; Informal Economy; Kampala; Democratization; Decentralization; Urban Development

Street vending has long been a major feature of Kampala's economic and physical landscape. As in so many other African cities, the practice serves as a key livelihood strategy for a segment of the urban poor for whom formal employment is unattainable and low entry costs are particularly appealing. A combination of high population growth, inadequate job creation and few protections for the unemployed and economically vulnerable means that for many, the unregulated sale of goods on city streets offers the only viable means of participating in a rapidly growing urban economy. It is a life of social and economic marginalization, but for an already disenfranchised group, the income that it provides is crucial.

The nature of street vending makes it fundamentally inseparable from the political environment in which it takes place. It is with the state that vendors must negotiate access to the public space that they depend on for their livelihoods, and it is the state's aspirations for urban management and development that street vendors must contend with or try to insert themselves into. The relationship that street vendors have with the state can define their very existence: if the

\footnotetext{
* This work was supported by the Smuts Memorial Fund, managed by the University of Cambridge in memory of Jan Smuts; and by the UAC of Nigeria Travel Fund.

${ }^{\dagger}$ The Version of Record of this manuscript has been published and is available in Journal of Eastern African Studies, September 2017, http://www.tandfonline.com/doi/full/10.1080/17531055.2017.1378448.
} 
state is accommodating, vendors can be free to trade on the streets with minimal hindrance and assert their right to participate in an urban economy from which they are otherwise excluded; if, on the other hand, the state is more hostile, then street vendors can face repression and active attempts to eradicate their activities, perpetuating their marginalization. This relationship is not merely static, but evolves over time as political conditions change and the ability of street vendors to influence decision-making expands and contracts as a result. The significance of such changes is particularly notable in Kampala, where street vendors have been profoundly impacted by the political evolution of the city under the National Resistance Movement (NRM).

This article explores how efforts by the NRM to monopolize political power in Kampala have defined the modern history of street vending in the city. It argues that political space in Kampala opened significantly as a result of the democratization and decentralization programs that the NRM introduced as a means of pursuing legitimacy after coming to power, and then closed when the central government reversed democratization and decentralization by taking over the city's government. Democratization and decentralization created a situation where a newly empowered city government, the Kampala City Council (KCC), was controlled by the opposition, and where major divisions between the opposition and the NRM led to an intense competition for popular support that street vendors were able to take advantage of as a key voting demographic. Seeking to regain control of the city, the central government replaced the KCC with a new city government, the Kampala Capital City Authority (KCCA), that is largely under the control of centrally appointed technocrats rather than elected politicians. Since the introduction of the KCCA, these technocrats have sought to secure their control over policy formation and implementation, further marginalizing elected officials. As a means of justifying its existence, the KCCA has introduced ambitious development and urban management initiatives aimed at transforming Kampala into a supposedly modern, orderly and well functioning city. Street vending, which has been framed as an embodiment of urban chaos, uncleanliness, insecurity and a lack of economic order - the antithesis of everything the KCCA stands for-has been banned and vendors face significant repression, while the closed political space that exists under the KCCA has meant that street vendors no longer have the ability to improve their conditions by exercising political influence.

The repression of street vending in Sub-Saharan Africa and beyond has received a considerable amount of scholarly attention. Studies often highlight the importance of 
colonialism, neoliberalism, development, urban governance and arguments about aesthetics and economic efficiency in efforts to remove vendors from city streets, suggesting that street vendors are commonly seen as undesirable as they violate dominant understandings of how and by whom urban space should be used. ${ }^{1}$ This article builds on these arguments by stressing how the repression of street vending can follow from broader institutional changes that are fundamentally driven by questions of political power and control. In Kampala, street vending was able to thrive as a result of reforms that the NRM introduced to solidify its position after coming to power; when the NRM later reversed these reforms and adopted an exclusionary form of urban management and development in an effort to regain control of the city, street vending suffered a precipitous decline. Since the KCCA adopted its ban on street vending in 2011, the number of vendors on the streets of Kampala has fallen from a total of 8,500 by perhaps $80-90 \%$, while those who remain regularly face harassment, fines, arrests and imprisonment. ${ }^{2}$ This dramatic change of fortune can only be understood in the context of the city's modern political history.

Following a brief overview of current literature on street vending in Sub-Saharan Africa and outline of its methodological approach, this article begins by exploring how the democratization and decentralization reforms introduced by the NRM dramatically reshaped the politics of Kampala, and how these new political realities allowed street vendors to remain on the city's streets by providing them with the opportunity to take advantage of a competitive political environment dominated by self-interested politicians. It then details how the ruling party subsequently reversed democratization and decentralization by replacing the KCC with the KCCA, and, by focusing on the politics of the KCCA between the 2011 and 2016 elections, describes how locally elected officials have been marginalized from decision-making. The extent to which the ruling party has justified its takeover of the city based on its apparent ability to promote development and undertake effective urban management is particularly emphasized. The final section of this article examines how the form of development and urban management that the KCCA has implemented has led to the repression of street vendors as undesirable elements of a modern urban landscape and economy, and how the organization's dedemocratized and highly centralized structure has robbed street vendors of the ability to exert the political influence that they previously enjoyed.

\section{Street vending in Sub-Saharan Africa}


Street vendors throughout Sub-Saharan Africa are commonly forced to contend with state efforts to regulate, limit or prohibit their activities. ${ }^{3}$ Current literature often focuses on the strategies that street vendors employ to negotiate access to urban space when confronted by the coercive power of the state, detailing how vendors respond to arrests, fines and relocation efforts by, inter alia, engaging in organizational advocacy, evading or bribing authorities, concealing merchandise, increasing mobility, establishing lookout and warning systems, selling at times of low police presence, switching activities after goods have been seized and returning to the streets following periods of repression. ${ }^{4}$ This work has provided valuable insights into the resilience and adaptability of a particularly vulnerable segment of the urban poor, and represents an important contribution to understandings of the broader struggles that define informal livelihood strategies across the continent. ${ }^{5}$

Rather than focusing on how vendors respond to state repression, this article instead turns its attention to how patterns of inclusion and exclusion are transformed over time as institutions and political circumstances evolve, and how this evolution is fundamentally driven by questions of power that dominate the interests of politicians and state officials. The central role that institutions play in shaping the politics of street vending has been highlighted by Skinner, whose comparative analysis of local government in South Africa and work on the changing treatment of street vendors in Durban since the end of apartheid offer a particularly valuable point of reference, ${ }^{6}$ and by Riley, who demonstrates the extent to which a flawed decentralization process and problems with the construction of local democratic institutions, along with the formation of a new governing party and the transformation of patronage networks, contributed to Operation Dongosolo, a major effort to eradicate street vending in Malawi in 2006. ${ }^{7}$ More generally, Brown and Lyons identify the institutional environment in which vendors' organizations operate as a critical determinant of their ability to exercise political influence and counter repression. ${ }^{8}$ This article contributes to this line of enquiry by exploring a case in which institutional and political transformation driven by the desire to monopolize power has had a severe and lasting impact on the fortunes of street vendors. The story of the decline of street vending in Kampala is the story of the politics of the city itself.

\section{Methodology}


This article combines primary and secondary research on the politics of street vending in Kampala. Semi-structured interviews were conducted with over 130 street vendors, government officials, civil society leaders, relevant professionals and other members of the city's informal economy in 2015. Respondents were asked a variety of questions surrounding the modern political history of Kampala and the changing role of street vending in the city's social, economic, political and physical landscape, and their answers provide the foundation of the arguments presented here.

Secondary research took two forms. First, major pieces of legislation and government documents were analyzed as a means of tracking how the nature and constitution of the state, as well as key internal state structures and policies, have evolved over time. This analysis plays an essential role in the descriptions of how political changes at both the national and local level have impacted street vendors in Kampala. Second, a comprehensive search through the archives of the country's two major daily newspapers, New Vision and The Daily Monitor, was also undertaken to complement insights gained from fieldwork and other documentary analysis, allowing a full picture of the politics of street vending in the city to emerge.

\section{Democratization, decentralization and street vending under the Kampala City Council}

Democratization and decentralization have been two key features of Uganda's political evolution under the NRM. Seeking to secure its position after coming to power in 1986, the NRM built upon the system of Resistance Councils that it had established during the civil war to introduce a radically new form of participatory local governance. The principle of devolving powers "from higher to lower local government units" in order to "ensure peoples' participation and democratic control in decision making" was enshrined in the country's 1995 Constitution, ${ }^{9}$ while the 1997 Local Governments Act formalized a five-tier system of Local Councils from the village (LC1) to the district/city level (LC5). ${ }^{10}$ The self-interest behind these reforms was clear: by constructing a seemingly inclusive system of government from the local to the national level, the NRM was able to expand its legitimacy and gain popular support throughout the country at the expense of traditional political parties, undermine calls for federalism by Baganda elites and secure crucial support from international donors. ${ }^{11}$ The NRM, of course, also strengthened its grip on power further by implementing democratization and decentralization in a way that allowed the central government to maintain significant control over all levels of local 
government under a system of effective one-party rule. ${ }^{12}$ Still, its reforms proved to be transformative.

This is particularly true in Kampala. ${ }^{13}$ Within the LC hierarchy, the Kampala City Council (KCC) became a city council (LC5) with a directly elected mayor and 31 elected councillors, above five city divisions (LC3) - Central Division, Kawempe Division, Lubaga Division, Makindye Division and Nakawa Division — each of which also had its own elected chairperson and councillors. Below the city divisions were a further 99 parishes (LC2) and 811 villages (LC1). ${ }^{14}$ The NRM also greatly expanded the powers of the KCC, devolving to it $80 \%$ of all services and leaving only national roads and secondary and post-secondary education under the control of the national government. ${ }^{15}$ Thus the twin processes of decentralization and democratization simultaneously gave the KCC more powers and autonomy over its affairs while also making its officials more subject to popular opinion and dependent on popular support.

While the NRM continued to dominate both national politics and the Local Council system across the country, the opposition established itself as the leading political force in Kampala under the KCC. In 1998, the city's first mayoral elections were won by multipartyist (the term for an opponent of the NRM's 'no-party' political system) and populist Nasser Ntege Sebaggala, who defeated incumbent and NRM favourite Christopher Iga in what was commonly seen as a rejection of President Museveni. ${ }^{16}$ Following Sebaggala's arrest and conviction in the United States for fraud related to forged traveller's cheques, a by-election held in 1999 was won by John Ssebaana Kizito, another multipartyist, who was re-elected in 2002. Sebaggala, after returning to Kampala in 2000 to what the BBC described as a "hero's welcome", was again elected mayor in 2006. ${ }^{17}$ Both Sebaggala and Ssebaana were widely known to be supporters of the Democratic Party (DP), the primary opposition force in the city, but ran as multipartyists before 2006 since the DP could not officially field candidates under the country's 'no-party' political system (and in 2006, Sebaggala ran as an independent due to conflicts with the DP leadership). The DP also controlled city council after the re-introduction of multi-party politics in 2005; from 2006-2011, 17 KCC councillors were DP members, 11 represented the NRM and three (including the mayor) were independents.

The opposition's power, however, was constantly challenged by the NRM, turning the KCC into what an article in the Daily Monitor referred to as "Uganda's main political battleground." 18 This mainly occurred in two ways: first, through direct interference, particularly 
by the President, in matters under the KCC's authority; and second, by denying the KCC essential funding and sources of revenue that it needed to properly function. These conflicts significantly undermined the KCC's ability to address the various developmental and urban management challenges that it faced, a reality that was often lamented by local politicians, including both Sebaggala and Ssebaana. ${ }^{19}$ Traffic congestion, poor roads and inadequate local service delivery such as garbage collection were constant problems in the city, while the KCC also oversaw the growth of informal structures and slum areas, the proliferation of boda-bodas (motorcycle taxis) and matatus (mini-buses), controversies surrounding the privatization of the city's markets and, as explored here, conflicts over street vending. ${ }^{20}$ Indeed, the growth of Kampala under the KCC occurred in such a way that one politician referred to the city, in a frequently quoted phrase, as a "modern executive slum". ${ }^{21}$

It is not simply the case, however, that the opposition-led $\mathrm{KCC}$ regularly attempted to implement forms of urban management that were ultimately and consistently undermined by the NRM. While this certainly occurred, the defining political reality of the KCC is that divisions between the NRM and the opposition in Kampala caused crucial issues pertaining to the government of the city to become politicized, and also caused concerns surrounding political advantage to supersede those of policy formation and implementation. This made politicians particularly dependent on popular support that was often tied to their willingness to further interests that were unrelated to governance. Such a reality provided space for street vendors to exercise political agency.

Street vending was officially regulated by the KCC. At a national level, the Trade (Licensing) Act of 1969 mandated that street vendors must possess a licence from a local authority outlining the type of goods they could sell, the area in which they could operate, the hours during which they could be on the street and "such other conditions as the [local] licensing authority may think fit to impose." 22 A license could be refused or revoked at any time, was valid for a year and had to be produced upon request. ${ }^{23}$ The KCC sought to implement further regulatory measures. It ordered vendors to be evicted in December $2000,{ }^{24}$ then did so again in July $2001^{25}$ and September 2001. ${ }^{26}$ In April 2002, the KCC undertook Operation Safe City, a major effort to remove vendors from the city's streets. ${ }^{27}$ Vendors largely complied with minimal confrontation, ${ }^{28}$ while those who did not faced prosecution. ${ }^{29}$ In 2006 , the KCC passed the Local Governments (Kampala City Council) (Maintenance of Law and Order) Ordinance, which 
banned all forms of street vending for those lacking official permits. ${ }^{30}$ The Town Clerk (the local administrative chief) again banned street vending in October 2010. ${ }^{31}$

Despite these efforts, street vending was still common under the KCC. Vendors were occasionally harassed, and periodic attempts to remove them from the city's streets certainly occurred, but orders to leave the streets were often ignored, or if they were followed, vendors would quickly return. It was the politics of the $\mathrm{KCC}$ that allowed this to happen. In a competitive electoral environment, KCC politicians effectively entered into what Tendler elsewhere calls a 'devil's deal' in which promises of protection are traded for political support from informal actors. $^{32}$ In simple terms, politicians and vendors in the city entered a tacit - and sometimes explicit-agreement in which access to space was effectively exchanged for votes; politicians, seeking advantage in Kampala's highly contested local politics and with the power to influence policy implementation, were willing to relax or undermine enforcement as a means of strengthening their political positions, allowing street vendors to use their position as a key voting demographic to pursue their political objectives. As a result, laws against street vending were inconsistently enforced by politicians who valued their positions of power more highly than city streets free of vendors. ${ }^{33}$ Vendors were aware of their own power when faced with evictions; Sebaggala himself reflected on the political pressure that street vendors could exert, complaining "Whenever I wanted to evict people who were trading in illegal areas, they would threaten that they would not vote for me again." 34 The demands of staying in office and gaining the upper hand in the constant struggles between the NRM and the opposition outweighed any concerns about eradicating street vending.

Street vendors also organized under the KCC to exercise their political agency. In fact, KCC officials supported organization as a means of facilitating revenue collection, promising further support. ${ }^{35}$ Street vendors who worked in shared geographic areas often organized in groups of various sizes, with the largest having at least a few dozen members who would elect leaders to serve specific administrative functions. These larger associations would support politicians who offered favourable treatment, and could also communicate with elected officials, particularly the mayor, on issues of primary importance to street vendors, including access to space, arrests, cleanliness and security. Politicians would not only offer protection and seek to solve conflicts in vendors' favour, but would also sometimes offer financial support for vendors to cover costs such as school fees. Associations would also organize revenue payments, and 
organize and assist payments on behalf of members related to permits, debts and bills in the event of illness or death. ${ }^{36}$ They had certain disciplinary functions as well, ensuring that only "honest" vendors were able to sell in their areas of influence. ${ }^{37}$

The NRM's democratization and, with decentralization, political empowerment of the KCC therefore had a profound effect on the agency of street vendors in Kampala. By giving local politicians extensive powers over the city's development and making them reliant on popular support for their positions, reforms created a political situation in which street vendors were able to leverage the support they could provide in exchange for favourable treatment from local authorities. The legal restrictions and occasional evictions that vendors in the city faced demonstrate the type of ambivalence that characterizes treatments of street vendors in a wide variety of settings. ${ }^{38}$ That ambivalence, however, was dependent upon the peculiarities of the political realities that existed in Kampala. When these realities changed, the ambivalence disappeared.

\section{The introduction of the Kampala Capital City Authority and the National Resistance Movement's reassertion of power}

If decentralization and democratization precipitated the rise of street vending in Kampala under the KCC, then a reversal of these processes led to its decline under a new recentralized, less democratic city government. The repression of street vending followed directly from the central government's takeover of the city, with the KCCA pursuing a form of development and urban management that excluded street vendors and street vendors lacking the opportunity for political influence due to the reduced space for political competition in a less democratic system of local government. The 'devil's deal' that street vendors were able to profit from under the $\mathrm{KCC}$ all but disappeared under the KCCA; no longer able to trade their political support for protection, vendors saw their space for agency greatly reduced.

\section{The Kampala Capital City Authority, 2011-2016}

The opposition's control of Kampala instilled in the central government a longstanding desire to take over the KCC and bring the city back under the direct control of the NRM. Both the President and supportive Members of Parliament (MPs) publicly expressed a desire to do so as early as $2001 .^{39}$ Under Article 202 of Uganda's 1995 Constitution, the President, with the 
approval of two-thirds of MPs, had the power to "assume the executive and legislative powers of any district" under the following conditions: "(a) where the district council so requests it and it is in the public interest to do so; (b) where a state of emergency has been declared in that district or in Uganda generally; or (c) where it has become extremely difficult or impossible for the district government to function." 40 Vague references to public interest and proper government functioning suggest that considerable room for interpretation surrounding the use of this power existed. The Constitution also stipulated, however, that the use of this power was to be temporary; the President could theoretically extend his control indefinitely, ${ }^{41}$ but the constitutionally stated final objective was to return power to the local government. ${ }^{42}$ This was not conducive to permanent political dominance.

The central government therefore needed a new legal basis on which to justify its takeover of Kampala. This came with The Constitutional (Amendment) Act of 2005, the same document that legislated a return to multipartyism and repealed Presidential term limits, making the central government's reassertion of power in Kampala an important part of the apparent trade-off that brought an end to the Movement system. ${ }^{43}$ Under Uganda's amended constitution, Kampala is listed as a distinct entity that is not classified with other regions and districts, thereby making it no longer subject to the provisions that apply to either, ${ }^{44}$ and is to be "administered by the central government" subject to provisions adopted by Parliament. ${ }^{45}$ In June 2009, Local Government Minister Adolf Mwesige presented to Parliament what would become, when eventually passed in November 2010, The Kampala Capital City Authority Act (KCCA Act).

The KCCA Act, in its final form, outlined the structure of the KCCA. The basic hierarchal structure of the local government system was maintained, as were some of the key features of the KCC, most notably the existence of a directly elected mayor, now with the title of 'Lord Mayor', along with 34 elected councillors (now with four elected by and to represent engineers, architects, doctors and lawyers). ${ }^{46}$ The position of Lord Mayor, however, was given reduced powers, assigned such functions as presiding over meetings, hosting dignitaries, monitoring administration, assisting in the administration of city divisions and performing "ceremonial functions and civic functions", although, significantly, it was also given the power to "head the Authority in developing strategies and programmes" for development. ${ }^{47}$ Much of the true power in the KCCA was to instead rest in the newly created position of Executive Director, the "chief executive" of the KCCA appointed by the President. ${ }^{48}$ The Executive Director was to 
be the head of the public service and administration, and among its various functions (23 outlined in the KCCA Act, compared to only eight for the Lord Mayor), was to oversee the KCCA's finances and assets, implement policy, enforce ordinances and byelaws, oversee service delivery and "mobilise the urban community for development and sustainability of infrastructure and services". ${ }^{49}$ The Executive Director was also supposed to "advise the mayor and Authority on Government policy" and "liaise with the central Government and other institutions on behalf of the Authority", tying the position even further to the central government. ${ }^{50}$ Both the Lord Mayor and Executive Director were to have deputies. ${ }^{51}$ Even with the presence of the Executive Director, there was also still to be a Resident City Commissioner (RCC) with the responsibility to "represent the President and the government". 52

Finally, there was to be a Minister for the KCCA in Parliament with the power to "give directives on policy and general development", "vary or rescind" decisions that are "in contravention of any law or Government policy" and "receive or take appropriate action" on reports submitted by the Lord Mayor, the Executive Director or a commission of inquiry. ${ }^{53}$ The Lord Mayor was to be answerable to the Minister and to the KCCA as a whole in the performance of his or her functions. ${ }^{54}$ As a Member of Cabinet appointed by the President, the KCCA Minister's ties to the central government were, like those of the Executive Director, also obvious.

The central government's takeover of Kampala was unsurprisingly met with resistance. Most notably, Sebaggala and Kampala Central MP Erias Lukwago criticized the move as a cynical and politically motivated attempt by the NRM to regain control of the city after long being unable to do so through electoral means. ${ }^{55}$ Sebaggala also warned that it would undermine the central government's decentralization efforts, and suggested that what the KCC truly needed was not to be replaced, but to be adequately funded and free from political interference. ${ }^{56}$ It was not just opposition politicians who were against the change. A poll conducted in 2008 found that of the $33 \%$ of Ugandans who were aware of the central government's plans, $38 \%$ approved and 59\% disapproved. Divisions were also notable across party lines: of the three main opposition parties, $91 \%$ of DP supporters, 69\% of Uganda People's Congress (UPC) supporters and 68\% of Forum for Democratic Change (FDC) supporters disapproved of the takeover, as did 63\% of independents and those supporting other parties, and, interestingly, $44 \%$ of NRM supporters. ${ }^{57}$ 
The KCCA was introduced on March 1, 2011. ${ }^{58}$ Although Kampala has traditionally been a stronghold of the opposition (particularly the DP), the NRM actually won the most council seats in the 2011 local elections. The DP also failed to win the mayor's office in each of the city's five divisions, and won fewer division council seats than the NRM in all divisions except for Lubaga. This can probably be explained in a large part by dissatisfaction with the DP's performance in managing the city. Still, support for the opposition was strong, and most notably expressed with the election of Erias Lukwago, the former MP for Kampala Central and a major opposition figure with the support of both popular opposition leader Kizza Besigye and the FDC, to the position of Lord Mayor with $64.41 \%$ of the vote. ${ }^{59}$ Jennifer Musisi, a lawyer with a background at the Uganda Revenue Authority, was appointed to the position of Executive Director by Museveni in 2011. Although Musisi was a technocrat rather than a politician, the unofficial requirement of sympathy for and a willingness to co-operate with the NRM in order to secure an appointment by the President is obvious. Beatrice Wabudeya, the Minister for the Presidency, was also named Minister for the KCCA in 2011, and was replaced in both these positions by Kabakumba Masiko, another NRM MP, who served until December of that year, being replaced, again in both positions, by Wilson Muruli Mukasa, a third NRM MP. Frank Tumwebaze, an NRM MP for Kibale County in Kamwenge District in Western Uganda, was appointed as both Minister for the Presidency and Minister for the KCCA in August 2012. The overlap of the two ministerial positions is particularly revealing about the close ties between Museveni and the KCCA hierarchy.

The NRM's efforts to expand its power in Kampala have continued after the introduction of the KCCA. While the KCCA has made the party (and, by extension, the central government) the dominant political force in the city, the fact that some positions in the city government are elected means that this dominance is not complete. This is something that the ruling party has sought to rectify, leading to conflicts between the political (elected) and technocratic (appointed) wings of the organization. The city's division mayors, including those belonging to the NRM, along with councillors within both the KCCA and city divisions have complained that Musisi and the technocratic wing make and impose decisions unilaterally. ${ }^{60}$ These particularly took the form of the technocratic wing, led by Executive Director Musisi, attempting to expand its power at the expense of the political wing, led by Lord Mayor Lukwago. Lukwago has been an outspoken opposition figure throughout his career. He has also been a prominent champion of 
the city's urban poor. This has made him extremely popular. As an MP he criticized both the performance of the KCC and the introduction of the KCCA, and later referred to his election as Lord Mayor as "a battle between me and the state" in which he "defeated President Museveni and the NRM rigging machinery". ${ }^{61}$ This victory, however, was short-lived. Lukwago quickly accused Musisi of overstepping her authority as Executive Director, claiming that she acted to construct and impose policies despite the fact that the KCCA Act, in his view, invested those powers within the body's political wing. ${ }^{62}$ This led to major disputes between the Lord Mayor and Executive Director about their respective powers within the KCCA, culminating in Lukwago's impeachment on November 25, 2013 for abuse of office, incompetence and misconduct or misbehaviour. ${ }^{63}$ Councillors who voted for Lukwago's impeachment reportedly received millions of shillings, along with young chickens and chicken feed, from the President. ${ }^{64}$ The decision was met protests in Kampala that were forcefully suppressed by the police. ${ }^{65}$

The contrast between the realities of the KCCA and the NRM's earlier stated commitment to decentralization and democratization is stark. The KCC was relatively autonomous and democratic, but this allowed it to be dominated by the popular opposition. Faced with a choice between political control and its twin programs of decentralization and democratization in Kampala, the central government emphatically chose the former, recentralizing power and de-democratizing the city through the KCCA. The politics of the city have been dramatically transformed as a result.

\section{Development and urban management}

It is crucial to stress the primary role that arguments about development and effective urban management played in justifying the introduction of the KCCA. The idea that the KCC was failing to adequately manage and oversee the development of the city was commonly held, and was, of course, tied to the political struggles that dominated the city: first, since politicians often pursued political advantage over governance functions; and second, because the central government could undermine the effectiveness of the $\mathrm{KCC}$, then use this ineffectiveness to point to the KCC's failure and its own obligation to replace a democratically elected government.

The logic of development and urban management featured prominently in the KCCA Act. Mwesige described the bill he presented to Parliament as "development-oriented", obviously implied to contrast with the performance of the KCC. ${ }^{66}$ Not only were the Lord Mayor 
and Executive Director given powers concerning the development and, particularly for the latter, management of the city, but a key feature of the KCCA was to be a new Metropolitan Physical Planning Authority to direct development in the city. The Metropolitan Physical Planning Authority, however, was never established, but a Physical Planning Committee was set up in accordance with the country's Physical Planning Act of 2010, and a detailed development plan for transforming Kampala into "a Modern, Functional Balanced City and Metropolitan System" was approved by the National Physical Planning Board in 2013. ${ }^{67}$

The KCCA wasted little time acting on its developmental and urban management ambitions. Many of the steps that it has taken have surrounded the performance of administrative duties, such as processing building plans, issuing permits and inspecting construction sites. ${ }^{68}$ It has also focused on high visibility "cosmetic projects" such as garbage collection and planting trees in order to demonstrate, according to one civil society leader, "that Kampala City, under the management of the opposition, was poor, compared to Kampala City under the management of the President and the Executive Director". ${ }^{69}$ Many of the KCCA's efforts, however, have been far more interventionist and coercive, perhaps most notably:

- The demolition of illegal structures around the city where owners lack proper permits and approval, including residences and commercial buildings;

- The eviction of tenants from places that serve important public functions, including Centenary Park, the city's wetlands and areas along the city's railway lines (with the railway line evictions alone affecting 40,000 people) $;^{70}$

- The demolition of traders' structures at such places as Luzira Stage Seven Market and the Old Taxi Park;

- Attempts to ban boda-boda stages from the city centre and take over the management of the matatu industry;

- Attempts to assume the management of and redevelop the city's markets; and

- The banning of begging on the city's streets and removals of street children.

The KCCA's efforts to eliminate street vending have been underpinned by the same logic of urban management and development. 


\section{The repression of street vending}

The repression of street vending in Kampala follows directly from the introduction of the KCCA. The KCCA's developmental ambitions caused it to commit to eradicating informal vending from the city's streets, while its recentralized and de-democratized structure closed the political space that street vendors had formerly used to exercise political influence. Lacking the political protection that they were able to access under the KCC, street vendors in Kampala have faced a city government that is far more committed to the eradication of their activities.

The Third Schedule of the KCCA Act gives the KCCA the power to "[p]rohibit, restrict, regulate or licence" street vending. ${ }^{71}$ The act also gives the Executive Director the power to "promote trade order" in the city, ${ }^{72}$ and the concept of 'trade order' is commonly referenced in the context of outlawing street vending. Ultimately, however, the KCCA justified its ban by invoking the 2006 ordinance passed by the KCC. ${ }^{73}$ This had two notable advantages: first, it meant that the KCCA did not need to pass its own legislation; and second, it served to contrast the effectiveness of the KCCA with the inability or unwillingness of the KCC to enforce its own adopted policies. Musisi announced a ban on street vendors in the city's Central Business District on July $102011,{ }^{74}$ and at the end of August the KCCA announced that vendors must vacate the city by September 4 or face evictions. ${ }^{75}$ Makiso, the Minister for the President and the KCCA, made a similar announcement on September $2 .^{76}$ The decision was apparently made by the central government. ${ }^{77}$

It is possible to identify four distinct arguments that are commonly employed to justify the KCCA's ban on street vending: ${ }^{78}$

1. Promoting cleanliness and order: street vendors are seen as a source of urban disorder and chaos who both are themselves unclean and make the city unclean with their presence. Such a view holds them to be not only detrimental to the city's aesthetics, but also to the city's proper and efficient functioning. A KCCA spokesperson claimed that the new city government "found the city in a mess" in 2011, with the streets "littered with vendors causing unnecessary traffic congestion" and impeding pedestrians on city sidewalks. ${ }^{79}$ Removing street vendors, according to this logic, was therefore essential to the effective management of otherwise open, unoccupied public spaces. 
2. Promoting security: street vending is also seen as a potential threat to public security. This often comes from the fear that street vendors may be criminals who could engage in petty thievery or even more serious crimes. The idea that criminals can pose as street vendors due to the low entry costs that characterize street vending has echoes in the similar (if more outlandish) fear that terrorists may do the same. Immediately before issuing the September 4, 2011 eviction deadline, Musisi said to journalists that "[i]n this era of terrorism and bomb threats", the government must be able to "control and regulate the number of illegal street vendors", suggestively adding that "no one knows the kind of merchandise they trade in." 80

3. Ending unfair competition: by operating on the streets, vendors are free from the taxes, regulatory costs and business expenses (particularly rent) that are more easily or inescapably incurred by their counterparts in shops. They also have easy access to potential customers due to the visibility and accessibility that comes with occupying public spaces. This gives them a major competitive advantage over (more) formal businesses that may be forced to charge higher prices for similar goods and may struggle to attract customers due to less favourable locations (something that is particularly relevant for businesses outside of the city centre, off of major streets or inside the city's indoor shopping arcades). Eradicating street vending would therefore benefit these businesses that 'play by the rules' by ensuring that they are no longer undercut by unfair competition.

4. Improving revenue collection: forcing vendors off of the city's streets and into markets could give them a more permanent position and ensure that they could be more effectively regulated and taxed. The KCC suffered from chronic financial problems that were in part caused by its poor performance in local revenue collection. The KCCA seeks to avoid the same fate.

These arguments reflect the idea that street vendors have no place in the modern urban economy and physical landscape that the KCCA has pledged to create. With their associations with urban disorder, a lack of cleanliness, criminality, terrorism, poor business performance and low revenue intake, street vendors are seen to embody the problems that prevent Kampala from becoming a modern, developed, well-managed city. In the context of the city's politics, they 
were, in 2011, a visible manifestation of the KCC's failure to promote development and undertake effective urban management; their removal, by contrast, would be a notable indication of the KCCA's superior ability to run the city, the primary justification given for the central government's takeover. The class dimensions of this logic are obvious: street vendors, as visible members of the urban poor, prevent the city from properly functioning for other residents by being visually unappealing, blocking traffic and pedestrians, posing a potential physical or monetary threat, undercutting businesses and undermining local government finances. Their livelihood needs are considered secondary to such concerns. ${ }^{81}$

These class dimensions are particularly evident from the major role that the Kampala City Traders Association (KACITA) played in promoting the ban on street vending in Kampala. KACITA, as the primary organization representing the city's traders, has long been a prominent opponent of street vending, regarding the practice as a source of unfair competition and an impediment to shop owners' access to potential customers. According to a KACITA spokesperson, the organization lobbied the KCC to remove vendors from the city's streets, but was unsuccessful because elected officials relied on street vendors for support. MPs and presidential candidates were apparently reluctant to act for the same reason. KACITA then lobbied Museveni, telling him to do a cost-benefit analysis of street vending that factored in revenue from taxes and licensing fees paid by formal businesses as well as potential security costs. The President was apparently persuaded by this logic, along with the fact that, with the 2011 elections over, he no longer needed street vendors' electoral support. ${ }^{82}$ Threats by KACITA to go on strike in September 2011 further pressured the KCCA to act to ban street vending when it did, ${ }^{83}$ just as a strike by traders to pressure the KCC into taking action in April 2002 was shortly followed by Operation Safe City. ${ }^{84}$

KACITA's efforts are in line with Cross' observation that businesses turn to the coercive powers of the state when they are unable to eliminate street vending through market competition. ${ }^{85}$ What makes street vending so attractive and gives it its competitive advantage is precisely its low entry costs and minimal capital intensity, making it accessible to the urban poor in a way that owning a larger business in a shop, with all of the costs that this would entail, is not. Larger traders wish to eliminate this competitive advantage, but in doing so close off one of the only avenues that the urban poor have for participating in the city's economy and securing a 
basic livelihood. Since the central government's takeover of the city, these traders, through the KCCA, have been able to get the state to intervene decisively on their behalf.

Political divisions, of course, also shaped the KCCA's ban on street vending. These cut across the obvious fault lines of power in the city under the KCCA: between the opposition and the ruling party, and between politicians and technocrats. Lukwago has been a particularly vocal critic of the evictions, accusing the KCCA of treating street vendors with an "iron fist" 86 and arguing before the ban took effect that more time should be allowed for proper consultations to take place. ${ }^{87} \mathrm{~A}$ number of opposition MPs-although not all-opposed the eviction in Parliament on similar grounds, but a motion to suspend it failed due to a lack of quorum. ${ }^{88}$ Lukwago also claimed that the decision to ban street vending was not properly discussed within the KCCA, leading to accusations that his powers were not adequately respected. ${ }^{89}$ This fuelled his conflict with Musisi and the KCCA's technocratic wing, forming a key part of disputes surrounding the proper division of powers and issues of development and urban management. These disputes have allowed Lukwago's opponents, including both Musisi and Museveni, to characterize him as an obstacle to development who stands in the way of the KCCA's plans and wastes valuable time and resources, ultimately justifying his removal.

Street vendors were largely seen to support Lukwago in his 2011 election victory, leading to speculation in the Daily Monitor as to whether or not this would be "his poisoned chalice when he moved to redeem the city" (that is, whether or not their support would prevent him from undertaking supposedly necessary evictions). ${ }^{90}$ In contrast to the KCC, however, the KCCA has been structured and operates in a way that renders the support of elected officials an ineffective way of exerting political influence. With the existence of the powerful technocratic wing that has taken over policy formation and implementation, along with continuous efforts to disempower the Lord Mayor, the KCCA imposes significant de jure and de facto restrictions on politicians that prevent them from coming to the aid of street vendors even when they desire to do so. Electoral competition has been minimized and its outcomes have been made less relevant, making the arrangement that existed under the $\mathrm{KCC}$ in which vendors could exchange electoral support for political protection practically impossible under the KCCA. Unelected technocrats are immune to such reasoning altogether, and because they derive their legitimacy from their ability to direct development and urban management, they have few reasons to sympathize with street vendors and strong reasons to pursue the eradication of street vending. As one (former) 
street vendor leader described, when vendors wanted anything under the KCC "they would run to the Mayor, they would run to MPs, they would run to councillors, but now with KCCA, they don't run to them because they don't have the power."91 The problem with the KCCA, another stated, is that "we have no right to vote for the Executive Director", and therefore no longer have the ability to influence local government policy. ${ }^{92} \mathrm{~A}$ third agreed, lamenting that the KCCA gets its orders from the President, and therefore has "no need to listen to us", 93 while another vendor similarly complained that decisions now come "from the State House" rather than elected local officials. ${ }^{94}$ The introduction of the KCCA has reversed democratization and decentralization in Kampala, and limited the political influence of street vendors as a result.

\section{Conclusion: the future of repression}

Street vendors in Kampala have faced significant repression since the introduction of the KCCA. Evictions, arrests, the confiscation or destruction of goods, demands for bribes and other forms of harassment by KCCA officials have become ever-present threats for street vendors who now ply their trade illegally. The organizations that they formed have been co-opted by the KCCA or have been coerced into disbanding, while the ones that remain have no real hope of influencing policy. The decentralized, democratized political system that empowered street vendors simply no longer exists, and the politicians who supported them no longer have the power or incentives to do so. As a result, the number of street vendors in Kampala has decreased dramatically. Some are in prison, or have been forced to give up vending because the costs associated with it have become too burdensome. Many have relocated to one of the city's informal markets, where they struggle with high fees and few customers. Others have left Kampala altogether, in many cases returning to the countryside after originally coming to the city in search of better economic opportunities. In short, street vendors have been excluded from the city's development, and have few prospects for improving their positions in a highly politicized urban economy.

The repression of street vendors shows little sign of ending. The 2016 elections saw Lukwago re-elected by an even larger margin than in 2011, while the NRM lost its majority of city council seats in the KCCA. Museveni too fared poorly, collecting fewer than half as many votes in Kampala as Besigye, his main rival, in his worst ever performance in the city. ${ }^{95}$ After his defeat in the city, Museveni suggested that the NRM may have performed so poorly in Kampala 
due to the KCCA's treatment of street vendors, and expressed his apparent displeasure with the fact that the evictions were carried out before a viable alternative for vendors to trading on the streets could be established. ${ }^{96}$ Street vendors apparently took these statements as a sign of support from Museveni, and returned to the city's streets in large numbers. Still, these changes were not enough to alter the long-term fortunes of street vendors. KACITA, as it did in 2002 and 2011, put pressure on the KCCA to carry out fresh evictions, which the KCCA did just weeks after the elections in an exercise that it dubbed 'restoration of trade order and sanity'. ${ }^{97}$ Whatever opening of political space the elections provided for street vendors proved to be short-lived. The repression of street vendors has resumed, and there is no evidence that the KCCA will change its policies on street vending. Its structure and operation give it little reason to do so.

Relief for street vendors in Kampala will only come from more fundamental structural change. The KCCA in its present form is not designed and does not function in a way that prioritizes responsiveness to popular input. Street vendors require inclusive decision-making processes in order to thrive in urban environments; anything less leaves them vulnerable to the often unforgiving vagaries of state power and developmental ambitions. The politics of Kampala, of course, will continue to evolve, but whether or not this will happen in a way that again accommodates street vendors remains to be seen.

\section{Notes}

1 These themes are explored to varying degrees in: Bromley, "Street Vending"; Crossa, "Resisting the Entrepreneurial City"; Mackie, Bromley and Brown, "Informal Traders"; Morange, "Street Trade"; Setšabi and Leduka, "Politics of Street Trading"; and Yamto, "Street Vendors".

2 The extent of the decline is based on the author's rough estimate made during the fieldwork undertaken for this study. For the number of street vendors before the ban, see Bwambale and Waiswa, "City Vendors".

${ }^{3}$ Mitullah, "Street Vending". Also see notes 4-8 below.

${ }^{4}$ See, for example: Asiedu and Agyei-Mensah, "Traders on the Run"; Brown and Lyons, "Seen but Not Heard"; Musoni, "Operation Murambatsvina"; Nduna, "The Struggles for Survival".

${ }^{5}$ See, for example: Hansen and Vaa, eds. Reconsidering Informality; and Lindell, ed. Africa's Informal Workers.

6 Skinner, "Getting Institutions Right?"; and Skinner, "Struggle for the Streets".

${ }^{7}$ Riley, "Operation Dongosolo". Also see Kayuni and Tambulasi, "Political Transitions".

${ }^{8}$ Brown and Lyons, "Seen but Not Heard".

9 “Constitution," Chapter Eleven, Article 176, Section 2, Subsection (b).

10 "Local Governments Act."

11 Carbone, No-Party Democracy?, 35; Rubongoya, Regime Hegemony, 60-69 and 104-112; Kasfir, "No-Party Democracy," 53; and Muhumuza, "Fundamental Change," 27.

12 Lambright, Decentralization in Uganda, 26-31; Tripp, Museveni's Uganda, 117-120; and "Hostile to Democracy," 74-78.

${ }^{13}$ See, for example: Goodfellow, and Titeca, "Presidential Intervention"; and Lambright "Opposition Politics".

${ }^{14}$ Stelman, "Organisational Performance," 7. 
${ }^{15}$ Goodfellow, "State Effectiveness," 90.

${ }^{16}$ Fisher, Ian, "Kampala Journal".

17 "Kampala Welcomes Fraudster Ex-Mayor".

${ }^{18}$ Tamale, "Political Interference".

${ }^{19}$ See, for example: Businge, "Government is Failing"; and Byenkya, "Politics Failed KCC".

${ }^{20}$ Each of these issues was widely commented on in the national media throughout the KCC's existence.

${ }^{21}$ Quote by Daniel Muliika, former politician in Buganda Kingdom. Cited in Lambright "Opposition Politics," 1.

22 "Trade (Licensing) Act," 1969, Section 16. Quoted from Subsection 3, 3.

${ }^{23}$ Ibid, Sections 16-19.

${ }^{24}$ Mwanje, "Traders Return".

${ }^{25}$ Kigozi and Musoke, "Vendors to Go".

26 "City Vendors Get Deadline," New Vision, 13 September 2001.

${ }^{27}$ Kamali, "KCC Battles Vendors Again"; and Kamali, "Vendors Get Friday Deadline".

${ }^{28}$ Mitullah, "Street Vending," 17.

${ }^{29}$ See, for example: "5 Convicted"; "156 Vendors"; and "Vendor Jailed".

30 "Local Governments," Part IV.

${ }^{31}$ Mwanje, "Town Clerk".

${ }^{32}$ Tendler "Small Firms".

${ }^{33}$ Respondents expressed a widespread agreement on this fact, both in positive (by vendors themselves) and negative (by those opposed to street vending) terms. As explored below, opposition to street vending was notably expressed in interview, KACITA representative, 11 July 2015. The phenomenon of selective enforcement due to political considerations is not unique to Kampala. See, most notably, Cross, Informal Politics.

${ }^{34}$ Quoted in Byenkya, "Politics Failed KCC".

${ }^{35}$ Interview, Usafi Vendors Association Member, 10 July 2015.

${ }^{36}$ Group interview, street vendors, 24 February 2015; group interview, Usafi Vendors Association, 18 July 2015; and interview, Usafi Vendors Association Member, 10 July 2015.

${ }^{37}$ Group interview, Usafi Vendors Association, 18 July 2015.

${ }^{38}$ Setšabi and Leduka. "Politics of Street Trading".

${ }^{39}$ Namutebi "Enter KCC Affairs"; and Namutebi, "Museveni Wants KCC Dissolved”.

${ }^{40}$ Quoted from "Constitution," Chapter Eleven, Article 202, Section 1.

${ }^{41}$ Ibid, Chapter Eleven, Article 202, Section 3.

${ }^{42}$ Ibid, Chapter Eleven, Article 202, Section 4.

43 "Constitution (Amendment) Act," Article 2 and Article 28; and "Constitution (Amendment) (No.2) Act," Article 2.

44 "Constitution of the Republic of Uganda: Amended by the Constitution (Amendment) Act," Act 11/2005, Chapter Two, Article 5, Section 2.

${ }^{45}$ Ibid, Chapter Two, Article 5, Sections 4 and 6.

46 "The Kampala Capital City Act," 2010, Part III, Article 6.

${ }^{47}$ Ibid, Part III, Article 11, Section 1.

${ }^{48}$ Ibid, Part III, Article 17, Sections 1 and 2.

${ }^{49}$ Ibid, Part III, Article 19.

${ }^{50}$ Ibid, Part III, Article 19, Subsections (e) and (o).

${ }^{51}$ Ibid, Part III, Article 9 and Part V, Article 23.

${ }^{52}$ Ibid, Part IX, Article 72, Section 1, Subsection (a).

${ }^{53}$ Ibid, Part XI, Article 79.

${ }^{54}$ Ibid, Part III, Article 11, Section 2.

${ }^{55}$ Mwanje, "No Justification"; and Kato, "Some Leaders".

${ }^{56}$ Maseruka, "Kampala Mayor".

${ }^{57}$ Gyezaho, "Ugandans Don't Want Govt".

${ }^{58}$ Interview subjects unanimously claimed that the KCCA was introduced in order to allow the central government to regain control of the city from the opposition. This was perhaps most notably expressed in: interview, KACITA representative, 11 July 2015; interview, Member of Parliament, Parliament of Uganda, 27 July 2015; group interview, Usafi Vendors Association, 18 July 2015; interview, Erias Lukwago, 10 August 2015; and interview, Uganda National NGO Forum spokesperson, 17 August 2015.

${ }^{59}$ Bareebe, "City Mayoral Seat"; and Kagolo and Ogwang, "Lukwago is Lord Mayor". 
${ }^{60}$ See, for example: Mukisa "KCCA Mayors, Councillors"; Nalugo, "Division Mayors Petition Parliament"; and Waiswa and Nantambi, “"KCCA Should Change”".

${ }^{61}$ Kiyonga, "How Museveni Plotted".

${ }^{62}$ Interview, Erias Lukwago, 10 August 2015.

${ }^{63}$ Bamugemereire, Lakidi and Okello, "KCCA Tribunal".

${ }^{64}$ Lubwama, "KCCA Councillors Get Cash".

${ }^{65}$ Masaba, "Teargas".

${ }^{66}$ Kato, "Some Leaders".

${ }^{67}$ Quoted in ROM Transportation Engineering Ltd. et al., "Kampala Physical Development Plan," 6. Also see "The Physical Planning Act."

${ }^{68}$ Email interview, KCCA spokesperson, 12 February 2016.

${ }^{69}$ Interview, Uganda National NGO Forum spokesperson, 17 August 2015.

${ }^{70}$ Kasozi and Namyalo, "Railway Evictions Case Adjourned".

71 "Kampala Capital City Act", Third Schedule, Part A, Article 3, Subsection (a).

${ }^{72}$ Ibid, Part III, Article 19, Subsection (q).

${ }^{73}$ Email interview, KCCA spokesperson, 11 November 2015.

${ }^{74}$ Mwanje and Ssenkabirwa, "KCCA Bows".

${ }^{75}$ Bwambale and Waiswa, "City Vendors".

${ }^{76}$ Bwambale, "Govt Orders Vendors".

${ }^{77}$ Ssempogo, Waiswa and Ssejoba, "Eviction of Vendors".

${ }^{78}$ These arguments were regularly put forth by interview respondents, and are commonly employed when street vending is discussed in the media.

${ }^{79}$ Email interview, KCCA spokesperson, 11 November 2015.

${ }^{80}$ See note 2 above. Interestingly, the only argument used in Kampala that is not identified in Bromley's comprehensive international overview from 2000 is the one relating to terrorism, pointing to a more common usage of security discourses and the impact this has had on the logic and rhetoric of development. See Bromley, "Street Vending".

${ }^{81}$ See note 38 above.

${ }^{82}$ Interview, KACITA representative, 11 July 2015.

${ }^{83}$ Mayanja, "Kampala Traders"; and Mwanje and Ssenkabirwa, "KCCA Bows".

84 "Kampala Businessmen Protest".

${ }^{85}$ Cross, "Street Vendors".

${ }^{86}$ Interview, Erias Lukwago, 10 August 2015.

${ }^{87}$ Mwanje, "Councillors, Lukwago Disagree"; and Waiswa and Asiimwe, "Lukwago Requests".

${ }^{88}$ Walubiri and Namutebi, "MPs Divided on Eviction".

${ }^{89}$ Bwambale and Mayanja. "Kampala Lord Mayor".

90 "The Huge Task".

${ }^{91}$ Group interview, Usafi Vendors Association, 18 July 2015

92 Ibid.

${ }^{93}$ Ibid.

${ }^{94}$ Group interview, Kampala Hawkers Association, 8 July 2015.

${ }^{95}$ Kiggundu, "Lukwago Win".

${ }^{96}$ Kiggundu, "Great Job"; and Kiyonga, "How Museveni Plotted".

${ }^{97}$ Busomoke, "KCCA Forces Vendors"; and Ojiambo, "KACITA, KCCA". 


\section{References}

"5 Convicted." New Vision, 11 May 2002.

"156 Vendors." New Vision, 3 June 2002.

Asiedu, Alex B. and Samuel Agyei-Mensah. "Traders on the Run: Activities of Street Vendors in the Accra Metropolitan Area, Ghana." Norsk Geografisk Tidsskrift - Norwegian Journal of Geography 62, no. 3 (2008): 191-202.

Bamugemereire, Catherine, Joska Ocaya Lakidi and Alfred Oryem Okello. "The Report of the KCCA Tribunal (2013).” November 2013.

Bareebe, Gerald. "How the City Mayoral Seat was Won." Daily Monitor, 16 March 2011.

Bromley, Ray. "Street Vending and Public Policy: A Global Review." The International Journal of Sociology and Social Policy 20, no. 1/2 (2000): 1-28.

Brown, Alison and Michal Lyons. "Seen but Not Heard: Urban Voice and Citizenship for Street Traders." In Africa's Informal Workers: Collective Agency, Alliances and Transnational Organization in Urban Africa, edited by Ilda Lindell, 33-45. London: Zed Books, 2010.

Businge, Conan. "Government is Failing City Council, Says Seya". New Vision, 3 December 2007.

Busomoke, Peter. "KCCA Forces Vendors Off Kampala Streets," New Vision, 11 March 2016.

Bwambale, Taddeo. "Govt Orders Vendors Off Streets." New Vision, 2 September 2011.

Bwambale, Taddeo and Brian Mayanja. "Kampala Lord Mayor Threatens to Resign." New Vision, 15 September 2011.

Bwambale, Taddeo and Juliet Waiswa, "City Vendors Told to Vacate," New Vision, 1 September 2011.

Byenkya, Alfred. "Politics Failed KCC, Says Sebaana". New Vision, 16 March 2011.

Carbone, Giovanni. No-Party Democracy? Uganda Politics in Comparative Perspective. Boulder: Lynne Rienner Publishers, 2008.

"Constitution of the Republic of Uganda." 1995.

Cross, John C. Informal Politics: Street Vendors and the State in Mexico City. Stanford: Stanford University Press, 1998.

Cross, John C. "Street Vendors, Modernity and Postmodernity: Conflict and Compromise in the Global Economy." International Journal of Sociology and Social Policy 20, no. 1/2 (2000): $30-52$.

Crossa, Veronica. "Resisting the Entrepreneurial City: Street Vendors' Struggle in Mexico City's Historic Center." International Journal of Urban and Regional Research 33, no. 1 (2009): 43-63.

Fisher, Ian. "Kampala Journal; When a Questionable Past Pays Political Dividends." The New York Times, 18 July 2000.

Goodfellow, Tom. "State Effectiveness and the Politics of Urban Development in East Africa: A Puzzle of Two Cities, 2000-2010." PhD diss., The London School of Economics and Political Science, 2012.

Goodfellow, Tom and Kristof Titeca. "Presidential Intervention and the Changing 'Politics of Survival' in Kampala's Informal Economy." Cities 29, no. 4 (2012): 264-270.

Gyezaho, Emmanuel. "Ugandans Don't Want Govt to Run City." Daily Monitor, 15 November 2008. 
Hansen, Karen Tranberg and Mariken Vaa, eds. Reconsidering Informality: Perspectives from Urban Africa. Uppsala: Nordiska Afrikainstitutet, 2004.

"Hostile to Democracy: The Movement System and Political Repression in Uganda," Human Rights Watch, 1999.

Kagolo, Francis and Patrick Ogwang. "Lukwago is Lord Mayor.” New Vision, 15 March 2011.

Kamali, Geoffrey. "KCC Battles Vendors Again.” New Vision, 2 May 2002.

Kamali, Geoffrey. "Vendors Get Friday Deadline." New Vision, 24 April 2002.

"Kampala Businessmen Protest Against Vendors." PanaPress, 22 April 2002.

"Kampala Welcomes Fraudster Ex-Mayor.” BBC News, 3 February 2000.

Kasfir, Nelson. “"No-Party Democracy” in Uganda.” Journal of Democracy 9, no. 2 (1998): 4963.

Kasozi, Ephraim and Jalira Namyalo. "Railway Evictions Case Adjourned.” Daily Monitor, 14 October 2014.

Kato, Joshua. "Why Some Leaders Are Against Government Take-Over of Kampala City." New Vision, 1 July 2009.

Kayuni, Happy M. and Richard I. C. Tambulasi. "Political Transitions and Vulnerability of Street Vending in Malawi." Theoretical and Empirical Researches in Urban Management 4, no. 3 (2009): 79-96.

Kiggundu, Edris. "Lukwago Win Bad for Museveni, Musisi." The Observer, 26 February 2016.

Kiggundu, Edris, "Musisi Doing a Great Job - Tumwebaze," The Observer, 2 March 2016.

Kigozi, Catherine and Cyprian Musoke. "Vendors to Go." New Vision, 20 July 2001.

Kiyonga, Derrick. "How Museveni Plotted Lukwago's Fall.” The Observer, 24 November 2013.

Lambright, Gina M. S. Decentralization in Uganda: Explaining Successes and Failures in Local Governance. Boulder: FirstForumPress, 2011.

Lambright, Gina M. S. "Opposition Politics and Urban Service Delivery in Kampala, Uganda." UNU-WIDER, Working Paper No. 2012/51, May 2012.

Lindell, Ilda, ed. Africa's Informal Workers: Collective Agency, Alliances and Transnational Organization in Urban Africa. London: Zed Books, 2010.

"Local Governments Act," 1997.

"Local Governments (Kampala City Council) (Maintenance of Law and Order) Ordinance," 2006.

Lubwama, Siraje, "KCCA Councillors Get Cash, Promised Chicks," The Observer, 29 August 2014.

Mackie, Peter K., Rosemary D. F. Bromley and Alison M. B. Brown. "Informal Traders and the Battlegrounds of Revanchism in Cusco, Peru." International Journal of Urban and Regional Research 38, no. 5 (2014): 1884-1903.

Masaba, Simon, "Teargas in Kampala After Lukwago Impeachment," New Vision, 25 November 2013.

Maseruka, Josephine. "Kampala Mayor Opposes City Take-Over." New Vision, 10 February 2010.

Mayanja, Brian, “Kampala Traders Call off Protests,” New Vision, 4 September 2011.

Mitullah, Winnie V. "Street Vending in African Cities: A Synthesis of Empirical Findings from Kenya, Cote D'Ivoire, Ghana, Zimbabwe, Uganda and South Africa." WIEGO, 16 August 2003. 
Morange, Marianne. "Street Trade, Neoliberalisation and the Control of Space: Nairobi's Central Business District in the Era of Entrepreneurial Urbanism." Journal of Eastern African Studies 9, no. 2 (2015): 247-269.

Mugisa, Anne. "KCCA's Musisi Beats Mayor Lukwago in Case Over Power." New Vision, 10 July 2012.

Muhumuza, William. "From Fundamental Change to No Change: The NRM and Democratization in Uganda." Les Cahiers d'Afrique de l'Est 41, no. 1 (2009): 21-42.

Mukisa, Farahani. "KCCA Mayors, Councillors Boycott Musisi Meeting." Daily Monitor, 22 June 2014.

Musoni, Francis. "Operation Murambatsvina and the Politics of Street Vendors in Zimbabwe." Journal of Southern African Studies 36, no. 2 (2010): 301-317.

Mwanje, Robert. "Councillors, Lukwago Disagree on Vendors." Daily Monitor, 3 September 2011.

Mwanje, Robert. "No Justification to Take Over Kampala City - Mayor." Daily Monitor, 11 December 2007.

Mwanje, Robert. "Town Clerk Bans Street Vending.” Daily Monitor, 12 October 2010.

Mwanje, Robert. "Traders Return to the Streets." Daily Monitor, 9 August 2007.

Mwanje, Robert and Al-Mahdi Ssenkabirwa. "KCCA Bows to Traders' Pressure, Evicts Vendors." Daily Monitor, 2 September 2011.

Nalugo, Mercy. "Division Mayors Petition Parliament Over Musisi." Daily Monitor, 5 August 2011.

Namutebi, Joyce. "Enter KCC Affairs, Govt Told." New Vision, 5 December 2001.

Namutebi, Joyce. "Museveni Wants KCC Dissolved.” New Vision, 20 June 2001.

Nduna, Joyce N. "The Struggles for Survival of Street Traders in Umtata, Transkei, 1980-89." GeoJournal 22, no. 3 (1990): 315-319.

Ojiambo, Benon. "KACITA, KCCA on Collision Course Over Street Vendors." New Vision, 1 March 2016.

Riley, Liam. "Operation Dongosolo and the Geographies of Urban Poverty in Malawi." Journal of Southern African Studies 40, no. 3 (2014): 443-458.

ROM Transportation Engineering Ltd., Shapira-Hellerman Planners, Larry Aberman \& Associates, Tzamir Architects and Planners Ltd and Ofek Arial Photography Ltd. "Kampala Physical Development Plan: Updating Kampala Structure Plan and Upgrading the Kampala GIS Unit.” Kampala Capital City Authority, Draft Final Report, September 2012.

Rubongoya, Joshua B. Regime Hegemony in Museveni's Uganda: Pax Musevenica. New York: Palgrave MacMillan, 2007.

Setšabi, Setšabi and Resetselemang Clement Leduka. "The Politics of Street Trading in Maseru, Lesotho." Urban Forum 19, no. 3 (2008): 221-241.

Skinner, Caroline. "Getting Institutions Right? Local Government and Street Traders in Four South African Cities." Urban Forum 11, no. 1 (2000): 49-71.

Skinner, Caroline. "The Struggle for the Streets: Processes of Exclusion and Inclusion of Street Traders in Durban, South Africa." Development Southern Africa 25, no. 2 (2008): 227-242.

Ssempogo, Herbert, Juliet Waiswa and Eddie Ssejoba. "Eviction of Vendors was Govt Policy, Musisi." New Vision, 7 September 2011. 
Stelman, Ursula M. "Understanding Organisational Performance in the City of Kampala: Implementation of Local Government Development Projects (2003-10)." Africa Power and Politics Programme, Working Paper 27, Overseas Development Institute, November 2012.

Tamale, Lillian. "Political Interference is Behind Poor Services in Kampala City." Daily Monitor, 21 September 2010.

Tendler, Judith. "Small Firms, The Informal Sector, and the Devil's Deal." IDS Bulletin 33, no. 3 (2002): 1-14.

"The Constitution (Amendment) Act." 2005.

"The Constitution (Amendment) (No.2) Act." 2005.

“The Huge Task Facing New Team Running Kampala.” Daily Monitor, 17 March 2011.

"The Kampala Capital City Act." 2010.

“The Physical Planning Act." Acts Supplement No. 5, 28 May 2010.

"Trade (Licensing) Act." 1969.

Tripp, Aili Mari. Museveni's Uganda: Paradoxes of Power in a Hybrid Regime. Boulder: Lynne Rienner Publishers, 2010.

"Vendor Jailed." New Vision, 12 July 2002.

Waiswa, Juliet and Brenda Asiimwe. "Lukwago Requests KCCA Chief Not to Evict Street Vendors." New Vision, 5 September 2011.

Waiswa, Juliet and Agnes Nantambi. "“KCCA Should Change its Mode of Work"." New Vision, 4 September 2014.

Walubiri, Moses and Joyce Namutebi. "MPs Divided on Eviction of Vendors." New Vision, 6 September 2011.

Yamto, Yandi Andri. "Street Vendors as 'Out of Place' Urban Elements." Journal of Urban Design 13, no. 3 (2008): 387-402. 